Mushenok Victor,

Doctor of Sciences (Law), Associate Professor, Kyiv National University of Trade and Economics, 19, Kyoto str., Kyiv, 02156, Ukraine ORCID: 0000-0003-0411-7567

Researcher ID: N-2296-2016 Sitnichenko Elena, $\mathrm{PhD}$ (Law Sciences), Kyiv National University of Trade and Economics, 19, Kyoto str., Kyiv, 02156, Ukraine

ORCID: 0000-0002-9740-0216

Researcher ID: M-5676-2016

\title{
TAX CONTROL AS AN ELEMENT OF TAX RELATIONSHIPS
}

Based on the research of individual elements of the legal mechanism of tax control found that the main form of tax control is a tax audit, which is the most effective method of identifying and ensuring payment of undeclared, not assessed and thus not included into budget taxes and is provided by comparing tax declarations (calculations) submitted by taxpayers, with actual data on their financial and economic activity. Proposals for improving the procedure for carrying out documentary checks by introducing amendments to the Tax Code of Ukraine and individual local regulations with a view to regulating tax legal relations and ensuring equality of taxpayers and state bodies in the process of verification are provided.

Key words: tax control, Tax Code of Ukraine, tax law, legal regulation.

Мушенок Віктор, Ситніченко Олена. Податковий контроль як елемент податкових відносин.

На підставі дослідження окремих елементів правового механізму здійснення податкового контролю встановлено, що основною формою податкового контролю $\epsilon$ податкова перевірка, яка є найбільш ефективним методом виявлення та забезпечення сплати не задекларованих, не нарахованих, не внесених податків до бюджету шляхом та забезпечується иляхом порівняння податкових деклараиій (розрахунків), щзо їх подають платники податків, з фактичними даними щодо їх фінансово-господарської діяльності. Надано пропозиції щодо удосконалення прочедури проведення документальних перевірок шляхом внесення змін до 
Податкового кодексу Украӥни та локальних нормативних актів Державної податкової служби України з метою урегулювання податкових правовідносин та забезпечення рівності платників податків та державних органів у прочесі здійснення перевірочної роботи.

Ключові слова: податковий контроль, Податковий кодекс Украӥни, податкове законодавство, правове регулювання.

Relevance of the research topic. Systemic changes in financial, economic and socio-political system that have taken place in Ukraine in recent years «have resulted in a transition from a planned economy based on overall and comprehensive state governance in all its spheres to a market economy, where the main influence of the state on economic processes is mediated through government regulation» (Illyenko P., 2017, p. 5). The sphere of state management of its external and internal functions with the help of finance is also subject to state regulation. Such regulation is aimed at the accumulation of funds into the state's property by means of legal mechanisms that ensure the process of taxation of individuals and legal entities. The direct mechanisms of redistribution of national income in the tax system of our state are taxes, fees, rentals and non-tax payments. Their functions determine their nature and are derived from the functions of finance. As tax payments perform similar tasks, but in a narrower range.

Formulation of the problem. The main function of taxes of any state is a fiscal function. According to this basic function, taxes fulfill their main purpose - to fill the revenue of the state budget of Ukraine and local budgets of all levels. Financial resources from tax revenues make the income of the state to meet the needs of society. Legal regulation of the tax system, that is - the tax legislation is formed in the direction of fiscal regulation of tax relations. In accordance with the principle of state fiscal sufficiency, the law establishes the procedure for administering taxes as a control over accrual, timeliness and completeness of transfers to the budget, and also the competence of state controlling bodies is determined on the same principle.

Analysis of basic research and publications. Among the domestic scientists dealing with the issues of tax legal research, analysis of the Tax Code of Ukraine and other acts of tax legislation, as well as the process of tax control, it is necessary to note the works of L. Demidenko, E. Dmitrenko, E. Krynitskii, M. Kucheryavenko, D. Lukianets, I. Ped', Y. Subbotovich, R. Usenko and others. However, constant changes in the strategic directions of domestic tax policy, as well as the adoption of a codified normative legal act of the tax legislation - the Tax Code of Ukraine in recent years, led to the lack of clear scientific regulation of the issues of definition in the mechanism for the implementation of documentary checks by state tax control bodies.

The purpose of this article is to implement a partial description of the legal mechanism for the implementation of tax control as one of the main elements of the regulation of tax relations and, based on the results of the study, to submit proposals 
for improving the norms of the Tax Code of Ukraine as regards the use of the procedure for conducting documentary checks by the bodies of state tax control.

Presenting main material. In the tax system of our state the main type of state financial control - tax control is regulated by the Tax Code of Ukraine (TC of Ukraine). According to the TC of Ukraine (item 41.1), it is determined that the controlling bodies are the bodies of incomes and charges - the central executive body, which ensures the formation of a single state tax, state customs policy regarding the administration of taxes and duties, customs payments and implements state tax, state customs policy, its territorial bodies (Podatkovyy kodeks Ukrayiny, 2010FF).

It should be noted that the main function of public financial authorities is to exercise control, which is a mandatory element of any field of public administration. Organization of control is an obligatory element in the management of public financial funds, since such a management entails a responsibility to society (Demidenko, L., 2017, p. 84).

The main goal of the government control bodies is to ensure strict observance of the provisions of tax legislation by taxpayers (individuals and entities). In our opinion, the level of efficiency of control activities of such bodies directly depends on the level of budget revenues, and the control itself "serves as a guarantee of satisfaction of public property interests and an important factor in the financial security of the state, its socio-economic stability and prosperity» (Demidenko, L., 2017, p. 45).

According to the current TC of Ukraine, the main form of tax control is tax audit. It is this form of control is most effective in terms of identifying and securing the payment of undeclared, not accrued or timely not included in budget taxes. Tax audits provide direct control over the completeness and accuracy of tax calculations, which can only be realized by comparing tax returns (calculations) submitted by taxpayers with actual data on their financial and economic activity.

According to the TC of Ukraine regulatory authorities have the right to conduct desk, documentary (scheduled or unplanned, on-site or off-site) and the actual verification (item 75.1) (Podatkovyy kodeks Ukrayiny, 2010). As a result of practical application of the TC Ukraine by regulatory authorities in the process of tax administration, particularly during the unscheduled inspections becomes apparent imperfection of certain financial provisions of law and the need to improve them by amending such act of tax legislation.

The subject of documentary verification is the timeliness, authenticity, completeness of accrual and payment of taxes and fees, as well as compliance with currency and other legislation, monitoring compliance is assigned to the regulatory authorities; employer compliance with legislation on the employment contract, registration of labor relations with employees (salaried individuals) and which is based on tax declarations (calculations), financial, statistical and other reporting, tax and accounting registers, which are provided for by law; primary documents used in accounting and tax accounting and related accrual and payment of taxes and fees; 
meeting the requirements of other legislation, monitoring compliance is assigned to the regulatory authorities as well as received in accordance with the procedure established by legislation by the controlling body of documents and tax information, including on the results of inspections of other taxpayers (Podatkovyy kodeks Ukrayiny, 2010).

It should be noted that the criterion for conducting documentary scheduled inspections is the risk of non-payment by taxpayers. The frequency of planned documentary checks is determined depending on the degree of risk in activities of such taxpayers. Inspections are provided in the schedule of documentary checks with such periodicity: taxpayers with a small degree of risk are included in the schedule not more than once every three calendar years, the average - no more than once every two calendar years, high - no more than one once per calendar year (Podatkovyy kodeks Ukrayiny, 2010).

Developing this wide general theoretical subject matter within the framework of financial and legal relations, it is necessary, in our opinion, to pay attention to the problematic issues of the imperfection of the legal mechanism for carrying out a documentary planned inspection of the taxpayer. In particular, in accordance with Paragraph 2, Clause 77.4, Article 77 of the TC of Ukraine, the right to carry out such verification is provided only in the case where the payer, not later than 10 calendar days before the day of the said inspection, has been handed over a receipt, or a written copy of the order on conducting the documentary planning check and written a notice indicating the date of commencement of such verification (Podatkovyy kodeks Ukrayiny, 2010).

In our opinion, the establishment of such a term significantly reduces the probability of ensuring the state control body of the control of compliance with the requirements of the rules of tax and customs legislation. The provision for advance notice to the payer of a documentary check must be deleted or the term should be reduced to three days.

This collective author's scientific position finds its confirmation of expediency in the analysis of prescriptions: Article 75 (Types of inspections), Article 78 (Procedure for carrying out non-scheduled documentary audits), Article 79 (Peculiarities of conducting documentary non-visiting checks) of the TC of Ukraine (Podatkovyy kodeks Ukrayiny, 2010).

In particular, the Tax Code of Ukraine states: 1) documentary unscheduled inspection is not provided for in the work plan of the controlling body and is conducted in case of at least one of the circumstances specified in this Code (paragraph 4, subsection 75.1.2, clause 75.1, Article 75);2) a documentary unscheduled non-direct verification is carried out by officials of the controlling authority solely on the basis of a decision of the head of such body, issued by an order, and provided that the taxpayer is notified of such decision in written form with a registered letter with confirmed delivery to him/her personally or his/her authorized representative of a copy of the order for conducting a documentary non-scheduled 
non-visiting inspection; and a written notice of the start date and place of such verification. Execution of the terms of this article gives the officials of the controlling body the right to start a documentary non-stop check (Clause 79.2, Article 79) (Podatkovyy kodeks Ukrayiny, 2010).

In our opinion, the legal mechanism of documentary off-schedule on-site verification is most effective in the implementation by the state authorities of measures to control the timeliness, reliability, completeness of accrual and payment of taxes, and also allows more expeditiously to detect violations of tax, currency and other legislation, including: the conduct of economic activity without state registration, concealment of employment relations with a hired workers, etc.

The analysis of the norms of the TC of Ukraine showed that the feasibility of carrying out the aforementioned changes in the legislation is confirmed by the information of the bodies of state tax control, which states that the most effective and operative means of detecting violations of tax legislation is precisely unscheduled inspections, which were carried out by the fiscal authorities on the basis of the fact that the results of inspections of other taxpayers or the receipt of tax information revealed facts indicating possible violations by the taxpayer of tax, currency and other legislation, the control of which is entrusted to the bodies of the bodies of state tax control (Chubarev, 2018V., p. 61).

Despite the apparent positive nature of such a legal mechanism for conducting documentary out-of-pocket checks, in our opinion, it needs some improvement. Article 78 of the TC of Ukraine, which regulates the procedure for carrying out such inspections, stipulates that a documentary off-schedule external check is carried out in case of at least one of the following circumstances: the results of inspections of other taxpayers or the receipt of tax information revealed facts indicating possible violations by the taxpayer of tax, currency and other legislation, the control of which is entrusted to bodies of the state tax service, if the taxpayer does not provide an explanation and documentary confirmation to the mandatory written request of the bodies of state tax control within 10 working days from the date of receipt of the request (Podatkovyy kodeks Ukrayiny, 2010).

From the analysis of the provision of this legal norm of the TC of Ukraine, it is obvious that the state provides the main guarantees for taxpayers when implementing tax control measures. However, in our opinion, it is necessary to remove from Article 78 of the TC of Ukraine on the rules for conducting a documentary tax audit only if the taxpayer does not provide explanations and their documentary confirmations to the mandatory written request of the state tax service body within 10 working days from the date of receipt of the request. Because under the conditions: presence of an act of verification of another taxpayer signed by officials of the body of the State Fiscal Service and by the taxpayer himself or his legal representative; obtaining tax information on possible violations by the taxpayer of the Constitution of Ukraine, the TC of Ukraine of other laws on taxation, current international treaties on taxation, 
the consent of which is binding on the Verkhovna Rada of Ukraine, decisions of local governments on local taxes and fees; it is evident that an unannounced documentary check is carried out immediately.

In addition, the provision of a ten-day period for the taxpayer to prepare a reply, with explanations and their documentary evidence, to the mandatory written request of the State supervisory authority, may lead to tax evasion or minimization through the cessation of activities or the abandonment by the officials of the location of the legal entity, etc., which will lead to the avoidance of financial, administrative or criminal liability.

Conclusion. The tax system is the main source of budget revenues an important element of market relations. From this point of view, the disclosure of the essence and the most important characteristics of the functioning of the tax control mechanism in the tax policy of Ukraine is relevant. Adoption of the TC of Ukraine made it possible to bring understanding of the main ideas of the tax policy to the taxpayer, by combining in one normative legal act of the material and procedural parties the regulation of the tax system. In particular, it was clearly stated in the codified normative act competence of the controlling bodies, the powers and responsibilities of their officials during the tax control.

As a result of the application of the TC of Ukraine by the controlling bodies in the process of tax administration, in particular when conducting unscheduled on-site inspections, it becomes apparent that the requirements of certain financial-legal norms of this act and the need for their improvement are becoming imperfect. That is why it is necessary to make changes in the procedure of tax authorities to carry out documentary planning and unscheduled inspections, by removing the rules on the possibility of conducting such inspections only subject to compliance with the ten-day period. As this norm makes it difficult and sometimes impossible to carry out effective and timely tax control and bring tax law violators to legal liability.

\section{REFERENCES}

1. Illyenko P. Financial Assistance under the Law of Ukraine (Monograph), 2017, 165 p.

2. Podatkovyy kodeks Ukrayiny. Zakon Ukrayiny, № 2755-VI vid 02.12.2010 («The Tax Code of Ukraine» Law of Ukrane) (n.d.), zakon.rada.gov.ua. Retrieved from: http://zakon1.rada.gov.ua/2010 (in Ukrainian)

3. Demidenko L., Subbotovich Yu. Tax system. (Center for Educational Literature), 2017. $227 \mathrm{p}$.

4. Chubarev V. 2009 International Economic Law. 2018, 368 p. 